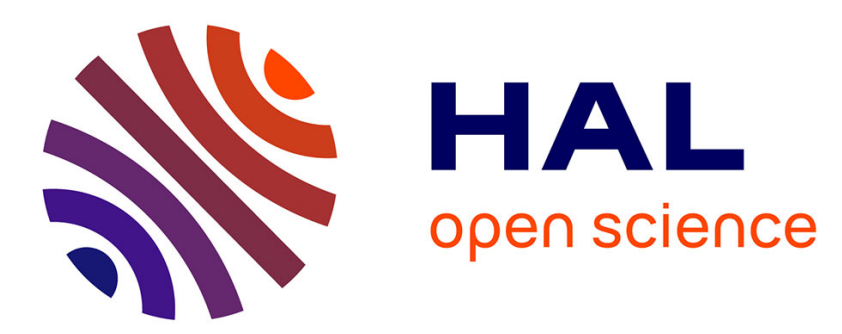

\title{
Life Cycle Analysis of Green Roof Implemented in a Global South Low-Income Country
}

Dominique Morau, N.Rabarison Tsiorimalala, Hery Tiana Rakotondramiarana

\section{To cite this version:}

Dominique Morau, N.Rabarison Tsiorimalala, Hery Tiana Rakotondramiarana. Life Cycle Analysis of Green Roof Implemented in a Global South Low-Income Country. British Journal Environment and Climate Change, 2017, ISSN:2231-4784, 7 (1), pp.43-55. 10.9734/BJECC/2017/30796 . hal01504422

\section{HAL Id: hal-01504422 \\ https://hal.science/hal-01504422}

Submitted on 2 Jul 2018

HAL is a multi-disciplinary open access archive for the deposit and dissemination of scientific research documents, whether they are published or not. The documents may come from teaching and research institutions in France or abroad, or from public or private research centers.
L'archive ouverte pluridisciplinaire HAL, est destinée au dépôt et à la diffusion de documents scientifiques de niveau recherche, publiés ou non, émanant des établissements d'enseignement et de recherche français ou étrangers, des laboratoires publics ou privés. 


\title{
Life Cycle Analysis of Green Roof Implemented in a Global South Low-income Country
}

\author{
Dominique Morau', Tsiorimalala N. Rabarison ${ }^{2}$ \\ and Hery T. Rakotondramiarana ${ }^{2^{*}}$ \\ ${ }^{1}$ Research Unit Piment, University of La Reunion, 117 Rue du Général Ailleret 97430, Le Tampon, \\ Reunion, France. \\ ${ }^{2}$ Institute for the Management of Energy (IME), University of Antananarivo, P.O.Box 566, \\ Antananarivo 101, Madagascar.
}

Authors' contributions

This work was carried out in collaboration between all authors. All authors read and approved the final manuscript.

Article Information

DOI: 10.9734/BJECC/2017/30796

Original Research Article

Received $1^{\text {st }}$ December 2016

Accepted $8^{\text {th }}$ March 2017

Published $30^{\text {th }}$ March 2017

\section{ABSTRACT}

Environmental protection becomes a global challenge currently. Green roof is one of the innovative concepts to face this battle. An increase in its use is noticed in urban areas worldwide. But a question arises: what are the environmental consequences of the green roofs' life cycle? In this paper, the environmental performance of two complete systems of lighter and heavier green roofs implemented in a global south low-income country are analyzed and compared in order to determine the potential impacts of both types of green roof systems. For proposing solutions aiming at reducing environmental loads of green roofs, Life-Cycle Assessment (LCA) approach was used in the present study. For this purpose, the approach consists of the following phases: definition of the objective, life cycle inventory, characterization of impacts, and interpretation of results. LCA calculations were done with the help of OpenLCA software. Results show that, non treated materials and / or imported ones are more environmentally impactful. Hence, it is profitable to reduce the use of cement, gravel, virgin plastics, and soil as well as imported materials whose transport is done by plane. In addition, use of natural fertilizer for amending the growth substrate and water from well for watering the green roof, is also recommended.

Keywords: Green roof; impact; climate change; Life-Cycle Assessment; OpenLCA.

*Corresponding author: E-mail: rktmiarana@yahoo.fr; 


\section{INTRODUCTION}

A green roof is a roof supporting a layer of soil in which grow vegetations. It is a green solution in urban areas [1]. Existing for centuries before Christ, this concept is used in many countries such as Canada, China, United States of America and some European countries. It has evolved and brings a lot of benefits: allowing energy savings for building heating in winter and decreasing the indoor temperature in summer [2, 3], protecting and extending the life of the roof membrane against extreme temperatures and their fluctuations [4]. Its use also improves sound insulation [5]; a $12 \mathrm{~cm}$ thick canopy layer reduces noises by about 40 to $50 \mathrm{~dB}$. Moreover, green roofs reduce the urban heat island effect as well. Works of [6] show a mitigating urban heat island by green roofs compared to roofs that are made of metal, asphalt or brick. The use of green roofs significantly contributes to the retention and purification of rainwater $[7,8]$. It also allows a capture of carbon dioxide and an improved air quality. Besides, a sharp increase of human activities on the exploitation of natural resources, manufacturing materials, transportation and urban construction, can be noticed. The amount of newly discovered resources continues to decline due to their limited and non-renewable characters [9]. Urban buildings are increasing and creating adverse effects on the environment [10]. Green roofs can be adopted to overcome these problems. Particularly regarding Madagascar, this big island is in a critical situation from an environmental perspective. The aforementioned benefits of green roof can contribute to reducing pollution problems in urban areas of Madagascar. However, it is essential to know the consequences of its implementation and usage.

Life-Cycle Assessment (LCA) increasingly becomes indispensable for having more environmentally friendly design of buildings as reported by review papers $[11,12]$. Several studies on the LCA of green roofs are currently available in the literature. The first two works implementing LCA methods were conducted by Saiz et al. [13] and by Kosareo and Ries [14] for showing the environmental benefits provided by green roofs in comparison with that related to conventional roofs. The former, who totally neglected the disposal phase of green roofs, found that cumulative annual energy savings caused by replacing the conventional flat roof with a green roof, allows reducing environmental impacts by between 1.0 and $5.3 \%$. On the other hand, the latter issued that though energy savings due to green roof's lower thermal conductivity are relatively modest with respect to the overall building energy use, it is significant for environmental impact over the life cycle of the building. Peri et al. [15], while applying LCA to extensive green roof, focused their attention on the disposal of substrate and on the impacts of fertilizers used during the operational phase, which seem to play an important role in the whole LCA balance. Besides, Tselekis [16] highlighted the potential energy savings and environmental benefits due to the use of green roofs by comparing construction costs and taking as references the conventional insulated and non-insulated roofing systems. Hong et al. [17] applied 16 improvement scenarios based on green roof systems in combination with energysaving measures for various weather conditions in South Korea; some of these scenarios were proven to be cost-effective. Blackhurst et al. [18] used LCA to assess the widespread installation of green roofs in a typical urban mixed-use neighborhood by taking into account the market prices of materials, construction, energy conservation, storm-water management, and greenhouse gas (GHG) emission reductions; results reveal green roofs are currently not cost effective on a private cost basis, but multifamily and commercial building green roofs are competitive when social benefits are included.

In addition, a certain number of LCA were carried out to evaluate the environmental impacts of various green roof constituent materials. For instance, while focusing their LCA work on polymers whose manufacturing process causes emission of harmful elements such as $\mathrm{NO}_{2}, \mathrm{SO}_{2}$, $\mathrm{O}_{3}$ and PM10 into air, Bianchini and Hewage [19] reported that the aforementioned air pollution can be balanced by the green roof's pollution removal capacity in 13-32 years. However, they recommended that low density polyethylene and polypropylene have to be replaced in the green roof component materials as their manufacturing process has many other negative impacts to the environment than air pollution. Rivela et al. [20], while applying LCA methods on different green roof constituent materials, found that the support layer which is made of concrete slab is the most impactful in all impact categories with the exception of the ozone layer depletion category; the most important impact contribution being due to thermal insulation made of concrete tile with extruded polystyrene and to felt wick irrigation system. Moreover, it is worth noting the work of Molineux et al. [21] though the utilized method 
was not exactly LCA, as they environmentally characterized four recycled materials that have been manufactured into useful substrates for use on extensive green roofs. While choosing the crushed red brick as an industry standard substrate control, three alternative pellets made from: clay- sewage sludge - fly ash mixture, recycled newspapers' ash, and carbonated limestone. Results revealed that these alternative substrates have great potential in the green roof market as they are as good, if not better, than the industry standard, both economically and environmentally.

Additionally, Chenani et al. [22] implemented LCA to two types of extensive green roof for determining the potential environmental impacts of different layers composing these green roofs. Their results highlighted that the water retention, drainage and substrate layers contained the most negative impactful components. Hence, they recommended the design of simple green roof systems whenever feasible as well as the use of recycled and local materials rather than virgin ones and those requiring long distance transports; use of compost on green roof is also recommendable as composting organic wastes seems better than landfill disposal; anyway, the use of Rockwool, virgin HIPS (High-Impact PolyStyrene) and expanded clay should be avoided. Rincón et al. [23] assessed, the environmental impact and the benefits of using recycled rubber crumbs from out use tires as a drainage layer in extensive green roofs, with the help of LCA in which performances of green roofs versus conventional ones were compared while considering the production, construction, operational, and disposal phases of roofing systems. It was concluded that the studied recycled rubber is environmentally friendly constructive material that should be recommended for use in buildings. Gargari et al. [24] focused their LCA work on the green roof soil for assessing the relevance of different growing medium types on the environmental impact of a green roof. It was concluded that adopting a proper design of the growing medium soil by taking into account all maintenance operations is crucial for a good green roof design. For that purpose, more complete information (such as thermal and water retention properties) about the growing medium available on the market are desirable.

Lamnatou and Chemisana [25] undertook LCA to evaluate environmental impact of a Photovoltaic (PV)-green roof along with other roof configurations: PV-gravel, green (extensive and intensive), gravel. While material manufacturing, material transportation, use/maintenance and disposal phases being considered in the LCA, the results revealed that material manufacturing is the most energy-demand phase for all the studied roofs and the additional environmental impact characterizing the PV-green system in comparison with the PV-gravel one can be balanced on a long-term basis. Then, Lamnatou and Chemisana [26] could determine the critical point after which PV-green roof becomes more eco-friendly than the other PV roofs by means of $\mathrm{ReCiPe}$ methodologies $[27,28]$.

As LCA software tools, commercial products, especially SimaPro [29], are the most used for the aforementioned LCA studies [13,14,19,23, 24]. As for the present work, environmental impacts of extensive and intensive green roofs located in a low-income country were assessed according to ISO 14040 [30] and ISO 14044 [31] standards. More precisely, special attention was paid on the impact of material transportation as the building location is in Antananarivo Madagascar. For that purpose, Ecoinvent v3.1 database [32] was used as database tool while OpenLCA [33] which is open source software freely available online was utilized as LCA tool.

Hence, this work aims at providing potential solutions for improving the environmental features of the green roof design and the manufacturing of materials used in its various component layers by using free LCA tools. That should enable to identify the best implementation scenario among various possible ones.

It is worth reminding that extensive green roof is lightweight while intensive one is a heavyweight version. From the bottom to the top layer, green roofs whose LCA is carried out in this study are assumed to be made of: a concrete, metallic or wooden structure for supporting all the other layers of the green roof, an impermeable membrane (synthetic rubber), an anti-root protection (polyethylene), a layer of draining and filtering (polyethylene), a growth substrate layer (soil and fertilizer) and a canopy layer (grass, sedum, shrub). Though polyethylene is among materials that should be replaced according to recommendations formulated by [19], it was used in the present study as there is no low cost replacement material available in the market on the basis of the authors' knowledge. 


\section{MATERIALS AND METHODS}

LCA is a systemic multi-criteria environmental approach. It only handles environmental impact of a product and ignores financial, political or other aspects. It consists of the following steps: 1) definition of the aim and scope of the study, 2) life cycle inventory, 3) characterization of impacts, and 4) interpretation of results [30]. It is based on the inventory of inputs (for example, raw materials, transport, process of energy conversion for the manufacturing and production of the studied product) and outputs (for example, emission of substances in soil, in water and in air). Hence, the potential impacts of each constituent layer of both aforementioned green roof types are evaluated and compared using this approach.

\subsection{Aim and Scope of the Conducted LCA}

The objective of the conducted LCA is to identify adverse effects of various constituent layers of a unit surface of green roof that is located in Antananarivo Madagascar, to the environment, human health and resource use. Then, solutions and remedies are especially proposed for mitigating these adverse impacts.

The functional unit adopted in this study is "the construction, the transmission and the use of 1 $\mathrm{m}^{2}$ of green roof for a period of one year, five years and ten years". A priori we have two types of green roof having a large difference of properties in terms of the amount of used products; the study of both cases allows a comparison and provides insights that help us either to improve green roof implementation or at least to have information for finding which kind of green roof is more convenient.

With respect to the system boundary, while mounting and end-of-life phases of the green roof being excluded, the following ones are included in the present study: manufacture and transport of various layers as well as the use of green roofs. In background, we have: the extraction of raw materials, energy conversion and supply, and waste production during the manufacture of various green roof layers. These data are already included in our database. Fig. 1 depicts the lifecycle process of green roofs and the system boundary.

The characterization methodology of impacts we have used in the simulation is the CML Baseline method, which is developed by the Institute of Environmental Sciences (CML) of the University of Leiden in Netherland, in the OpenLCA software [33]. This modeling method corresponds to the first order effects: quantifiable and relatively straightforward, thus with small uncertainty but little talking [34].

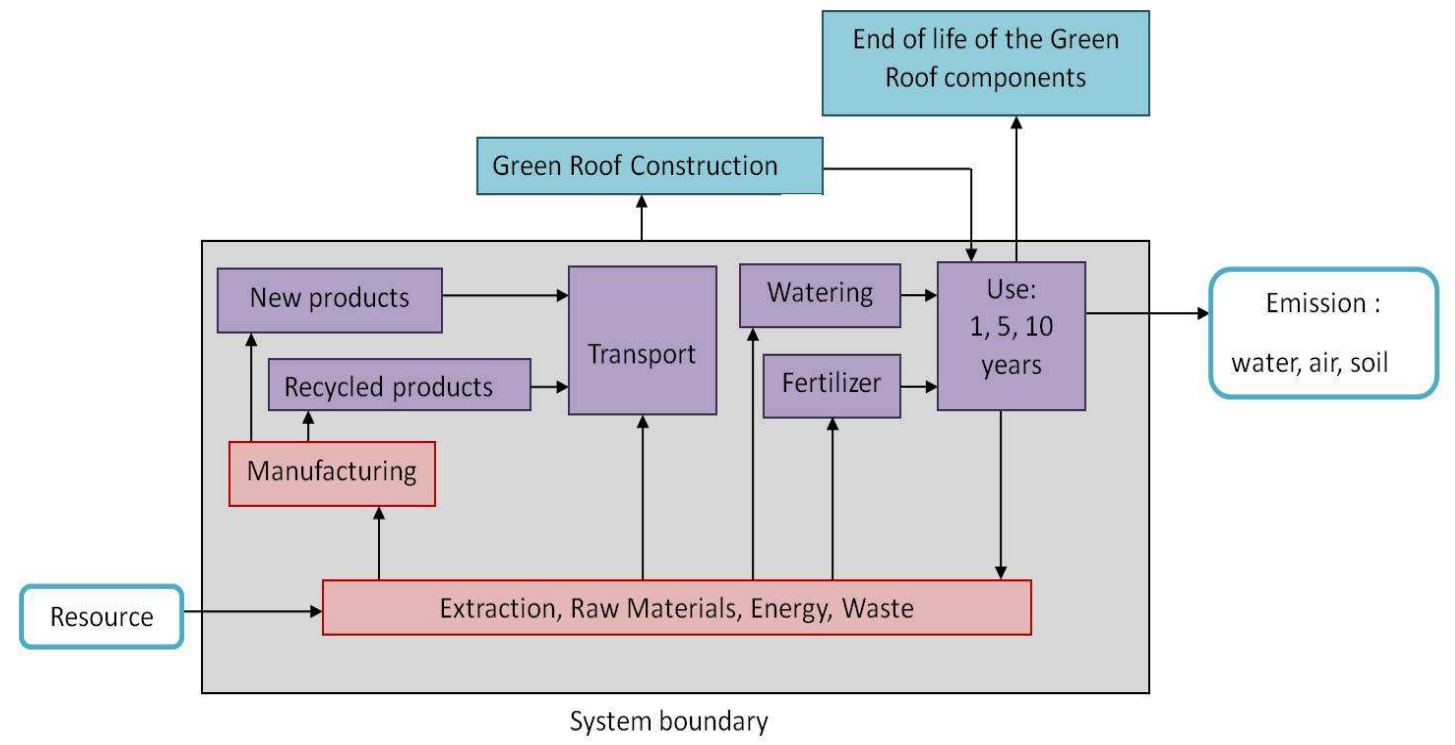

: Leading process

: Background process

: Unstudied process

Fig. 1. Lifecycle process of green roofs and the system boundary 


\subsection{Life Cycle Inventory}

As being mentioned previously, OpenLCA software [33] was used to achieve all simulation steps. All used data are identified from different companies and experts while referring to the green roof design guidelines that are proposed by Peck and Kuhn [35] which shows the amount of materials used in the design of green roofs. Ecoinvent (version 3.1) database [32] from which resources come is adjoined into this software. For carrying simulations, green roof was assumed to be constituted by some layers as illustrated in Fig. 2. For the characteristics of these different layers in the scenarios, we used data from [36].

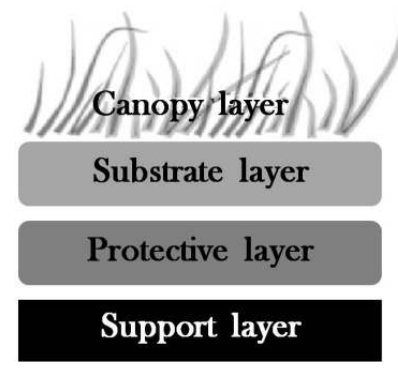

Fig. 2. Various layers constituting a green roof

\subsubsection{Extensive green roof scenario}

\subsubsection{Canopy layer}

The canopy layer is the most essential part of the green roof. While the adopted support being lighter as can be seen in further subsection, the selected vegetation for this kind of roof is herbaceous, more precisely grass, as it is very variable in quantity and grows over time. For this study, a unit area of the canopy layer is made of about $1 \mathrm{~kg}$ of grass having a thickness of $0.02 \mathrm{~m}$.

\subsubsection{Growth substrate layer}

The growth substrate layer is also essential for the green roof as it serves the nutrition of vegetation and plays an important role in managing storm water. For this first type of green roof, the substrate is made of soil that is mixed with compost in the ratio of $100 \mathrm{~kg}$ and $25 \mathrm{~kg}$ respectively, while having a thickness of $0.15 \mathrm{~m}$.

\subsubsection{Protection layer}

The protection layer is composed of two plastic materials. The first one is anti root barrier made of high density polyethylene: $0.76 \mathrm{~kg}$ of weight and $0.0008 \mathrm{~m}$ of thickness. This layer is needed to prevent root penetration into the support. The other one is a layer of drainage and filtration consisting of virgin polystyrene: $0.68 \mathrm{~kg}$ of weight and $0.008 \mathrm{~m}$ of thickness. The filter is used to filter fine particles from the substrate while the drainage layer which looks like an egg box allows the free flow of water.

\subsubsection{Support layer}

Pine wood was selected as material of the support layer which is vital as it supports all the above mentioned different layers of the green roof; it weighs $25 \mathrm{~kg}$ (per unit surface) and is $0.15 \mathrm{~m}$ thick. Table 1 lists the transport of materials for extensive green roof.

Maintenance items on the functional unit during the roof-use are watering and addition of substrate on the canopy and soil layers. In terms of resources, $20 \mathrm{~kg}$ of fertilizer and $96 \mathrm{~kg}$ of water per unit area of the green roof should be added. With the help of database, the following process was considered "Tap water production underground water without treatment - Rest-ofthe-World (RoW)" and "Field application of compost-RoW". The quantities of required inputs are calculated according to the use period of the considered product.

Table 1. Transport of extensive green roof materials

\begin{tabular}{lllll}
\hline Layer & $\begin{array}{l}\text { Transport, freight, } \\
\text { lorry 3.5-7.5 } \\
\text { metric ton, } \\
\text { EURO3-RER }\end{array}$ & $\begin{array}{l}\text { Transport, freight, } \\
\text { lorry 3.5-7.5 metric } \\
\text { ton, EURO3-RoW }\end{array}$ & $\begin{array}{l}\text { Transport, freight, } \\
\text { light commercial } \\
\text { vehicle-RoW** }\end{array}$ & $\begin{array}{l}\text { Transport, } \\
\text { freight, sea, } \\
\text { transoceanic } \\
\text { ship-GLO* }\end{array}$ \\
\hline Canopy & - & - & $30 \mathrm{~km}$ & - \\
Substrate & - & - & $20 \mathrm{~km}$ & - \\
$\begin{array}{l}\text { Protection } \\
\text { Support }\end{array}$ & $225 \mathrm{~km}$ & $365 \mathrm{~km}$ & $20 \mathrm{~km}$ & $8938 \mathrm{~km}$ \\
\hline \multicolumn{5}{c}{${ }^{*}$ Abbreviations being region codes used by ecoinvent for indicating the geography such that: } \\
Global (GLO), Europe (RER), the Rest-of-the-world (RoW)
\end{tabular}




\subsubsection{Intensive green roof scenario}

The component materials of intensive green roof are listed in Table 2. It was assumed that only support and protection layers change during transport.

For the support layer, cement undergoes two types of transport: one by truck and another one by commercial car, over distances of $190 \mathrm{~km}$ and $20 \mathrm{~km}$ respectively. Additionally, we made the assumption that steel comes from South Africa, by 4 types of transportation means: rail, sea, truck and commercial car over distances of 210 , 2617.92, 365 and $20 \mathrm{~km}$ respectively. Gravels are transported by road on a commercial transport route over $20 \mathrm{~km}$.

With respect to the protection layer, after a commercial car transport of about $20 \mathrm{~km}$ to the airport, it is conveyed by aerial transport from Europe to Antananarivo of $5655 \mathrm{~km}$ of distance, and then it is again transported by commercial car over a distance of $50 \mathrm{~km}$.

In addition, $150 \mathrm{~kg}$ of fertilizer and $730 \mathrm{~L}$ of water are added to the green roof annually. The process data that are taken into account in the present study are related to the production of cement, steel, gravel, polyethylene, polystyrene, wool, cracked tile, fertilizer, and bush.

\subsection{Impact Assessment}

This step converts inventory data in indicators that characterize the potential effects on human health and on the environment of the considered product during its life cycle [28]. We used the latest version of CML Baseline method. It presents ten categories of environmental impacts, but we only present 3 that are of interest and relevant to the case of Madagascar as shown by Table 3 .

Table 2. Component materials of intensive green roof

\begin{tabular}{|c|c|c|c|c|}
\hline Layer & Product & Material & $\begin{array}{l}\text { Weight } \\
\left(\text { kg. } \mathbf{m}^{-2}\right)\end{array}$ & $\begin{array}{l}\text { Thickness } \\
\text { (m) }\end{array}$ \\
\hline \multirow[t]{3}{*}{ Support } & Concrete & Cement & 75 & 0.15 \\
\hline & & Steel & 25 & \\
\hline & & Gravel & 150 & \\
\hline \multirow[t]{3}{*}{ Protection } & Anti-root barrier & $\begin{array}{l}\text { Recycled LDPE (Low } \\
\text { Density PolyEthylene) }\end{array}$ & 0.175 & 0.0002 \\
\hline & $\begin{array}{l}\text { Drainage and } \\
\text { filtration }\end{array}$ & $\begin{array}{l}\text { Recycled HIPS (High- } \\
\text { Impact PolyStyrene) }\end{array}$ & 1.252 & 0.05 \\
\hline & Water reserve & Hydrophilic mineral wool & $\begin{array}{l}6 \text { (dry) } \\
46 \text { (saturated) }\end{array}$ & 0.0275 \\
\hline Substrate & $\begin{array}{l}\text { Mixture of recycled } \\
\text { soil and organic } \\
\text { fertilizer }\end{array}$ & $\begin{array}{l}\text { Crushed tile } \\
\text { Poultry manure }\end{array}$ & $\begin{array}{l}200 \\
50\end{array}$ & 0.40 \\
\hline Canopy & Vegetation & Low growth bushes & 10 & 1 \\
\hline
\end{tabular}

Table 3. Descriptions of selected impact categories

\begin{tabular}{|c|c|c|c|}
\hline Category of impact & Indicator & Unit & Description \\
\hline Climate change & $\begin{array}{l}\text { GWP100 (Global } \\
\text { Warming Potential) }\end{array}$ & $\mathrm{Kg} \mathrm{CO}_{2}$ eq. & $\begin{array}{l}\text { The product's impact on } \\
\text { global warming over } 100 \\
\text { years. }\end{array}$ \\
\hline $\begin{array}{l}\text { Depletion of abiotic } \\
\text { resources }\end{array}$ & Fossil fuels & MJ & $\begin{array}{l}\text { Characterization of } \\
\text { emissions of greenhouse } \\
\text { gases in the air. }\end{array}$ \\
\hline Human toxicity & $\begin{array}{l}\text { HTP inf. (Human } \\
\text { toxicity Potential) }\end{array}$ & $\begin{array}{l}\mathrm{Kg} 1.4- \\
\text { dichlorobenzene } \\
\text { eq. }\end{array}$ & $\begin{array}{l}\text { The potential effect on } \\
\text { humans of toxic } \\
\text { substances emitted into } \\
\text { the air, water and soil. }\end{array}$ \\
\hline
\end{tabular}


We chose the Global Warming Potential (GWP) with a 100 year time horizon as it is the most widely used indicator. It represents the duration of human life and was selected in the Kyoto Protocol Article 5-3. We also need a long time span to see the change caused by global warming (for example: increase of sea levels).

\section{RESULTS AND DISCUSSION}

\subsection{Phase 1: Production of Various Green Roof Constituent Layers}

Simulation results obtained from OpenLCA [33] are presented in Table 4 which compares production impacts of various constituent layers of both considered green roof types.
Compared to wood use, cement production impacts $53 \mathrm{~kg} \mathrm{CO}$ equivalent more while steel manufacturing causes only $5.3 \mathrm{~kg} \quad \mathrm{CO}_{2}$ equivalent of additional impacts. In terms of resource consumption, cement production consumes 15 times more compared to steel fabrication. On human toxicity, cement production is always the most impacting with a value of $5.288 \mathrm{~kg}$ 1.4-dichlorobenzene equivalent. Generally, impacting substances are those that are released during various stages of production or transport rather than those contained in the product unless they are toxic ones. Cement is produced by combustion of limestone and other additives at very high temperatures. Such combustion rejects flying ashes and fine mineral particles which can be carcinogenic to humans [37].

Table 4. Comparison of production impacts of both green roof types' layers

\begin{tabular}{|c|c|c|c|c|}
\hline Layer & Category of impact ${ }^{\star}$ & $\begin{array}{l}\text { Climate } \\
\text { change - } \\
\text { GWP100** } \\
\text { (Kg CO } 2 \text { eq.) }\end{array}$ & $\begin{array}{l}\text { Depletion } \\
\text { of abiotic } \\
\text { resources } \\
\text { (MJ) }\end{array}$ & $\begin{array}{l}\text { Human toxicity - } \\
\text { HTP inf. } \\
\text { (Kg 1.4- } \\
\text { dichlorobenzene eq.) }\end{array}$ \\
\hline \multirow[t]{4}{*}{ Support } & Woodwool production-RoW* & -15.861 & 11.087 & 0.368 \\
\hline & Gravel production, crushed-RoW & 0.657 & 8.026 & 0.631 \\
\hline & $\begin{array}{l}\text { Cement production, pozzolana } \\
\text { and fly ash } 11-35 \% \text {, non-US }\end{array}$ & 89.148 & 318.375 & 7.931 \\
\hline & $\begin{array}{l}\text { Steel production, low-alloyed, hot } \\
\text { rolled-RoW* }\end{array}$ & 2.905 & 36.949 & 2.777 \\
\hline \multirow[t]{4}{*}{ Substrate } & $\begin{array}{l}\text { Field Application of compost- } \\
\text { RoW }^{*}\end{array}$ & 19.982 & 260.66 & 10.479 \\
\hline & $\begin{array}{l}\text { Land already in use, arable land- } \\
\text { GLO* }\end{array}$ & 40.625 & 84.084 & 10.372 \\
\hline & $\begin{array}{l}\text { Field application of poultry } \\
\text { manure }- \text { RoW }^{*}\end{array}$ & 4.136 & 257.329 & 13.172 \\
\hline & $\begin{array}{l}\text { Concrete roof tile production- } \\
\text { RoW }\end{array}$ & 59.7 & 357.748 & 17.224 \\
\hline \multirow[t]{5}{*}{ Protection } & $\begin{array}{l}\text { Polyethylene production, linear } \\
\text { high density, granulate-RER }{ }^{\star}\end{array}$ & 1.494 & 50.589 & 0.064 \\
\hline & $\begin{array}{l}\text { Polyethylene production, low } \\
\text { density, granulate-RER }{ }^{\star}\end{array}$ & 0.333 & 10.303 & 0.018 \\
\hline & $\begin{array}{l}\text { Polystyrene foam slab } \\
\text { production, } 100 \% \text { recycled-RER* }\end{array}$ & 0.461 & 6.477 & 0.142 \\
\hline & Polystyrene, high impact -RER* & 2.307 & 51.446 & 0.215 \\
\hline & Woodwool production-RER* & -3.45 & 5.929 & 0.266 \\
\hline \multirow[t]{2}{*}{ Canopy } & $\begin{array}{l}\text { Grass production, permanent } \\
\text { grassland, organic, extensive- } \\
\text { RoW* }\end{array}$ & -2.746 & 1.081 & 1.081 \\
\hline & $\begin{array}{l}\text { Grass production, organic, } \\
\text { intensive }- \text { RoW }^{*}\end{array}$ & -6.277 & 2.471 & 0.029 \\
\hline
\end{tabular}


For the protection layer: materials that are used for extensive green roof are more impacting compared to those related to intensive green roof. Indeed, high density materials which require more resources are employed for extensive green roof. These materials are more impacting due to their impurities which contain noxious and polluting substances. The use of recycled materials and low density has less impact. For example, polystyrene which comes from benzene hydrocarbon is toxic if inhaled. However, the recycled polystyrene is less toxic as more than $60 \%$ of the aforementioned pollutants are already eliminated in the recycling process.

With regard to the substrate layer: the choice of substrate components is an important part in the implementation of a green roof. It can be noted in the inventory that the substrate amount of intensive green roof is twice that of the extensive green roof. Then in the climate change section, the use of crushed tile is beneficial as this material is recycled; it enables to halve the amount of the required substrate, for example. Nonetheless, the use of soil is more advantageous in terms of resource consumption. This is due to energy consumption related to the tile crushing. For the choice of fertilizers, here the use of the material for intensive green roof is twice that for extensive green roof. However, the global warming category result shows that the use of compost is 5 times more impacting than the use of manure from poultry. For resource depletion, compost consumes twice more resource for identical amounts of material contained in both kinds of manures. All this comes from the production, transportation and spreading of compost which requires the use of mechanical and motorized vehicles which are major consumers of resources and are sources of pollutant emissions (carbon dioxide and fine particles) in large quantities. Compost is not intended for use on green roofs initially, but it enables to avoid landfill disposal [22]. Thus, it is better to use natural products requiring no treatment as fertilizer.

With respect to canopy layer: for all impact categories, we can see from these results that the environmental impacts are proportional to the amount of used vegetation for the roof type. Therefore, the intensive green roof presents more impacts than the extensive one. Inversely, this latter has negative effects on climate change, which are advantages.

\subsection{Phase 2: Transportation of Materials to the Building Site}

Fig. 3 presents the comparison of material transportation impacts for both green roof types.

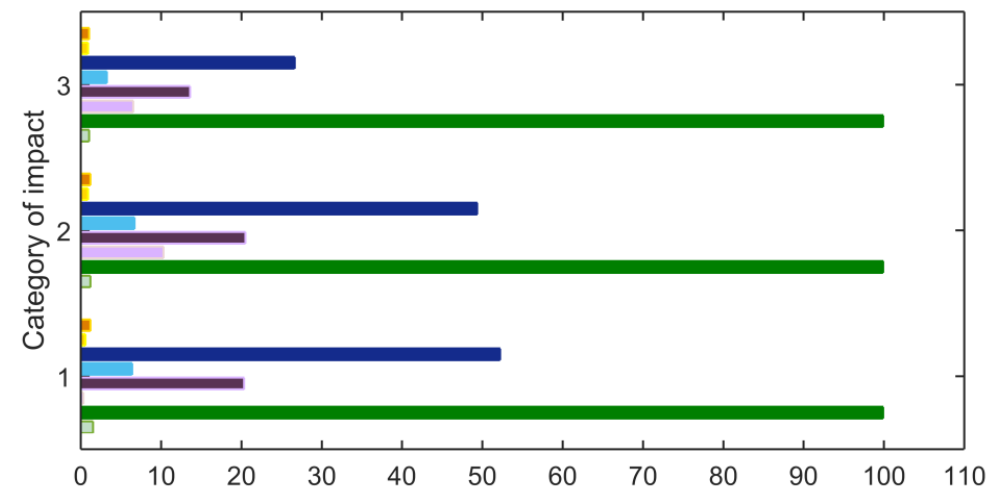

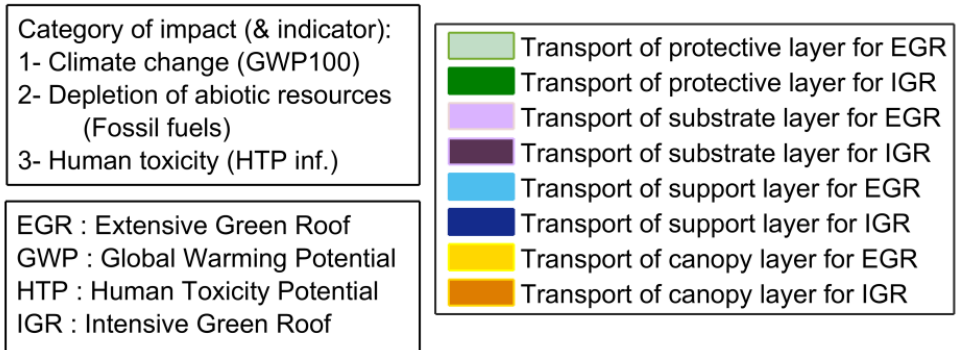

Fig. 3. Comparison of material transportation impacts for both green roof types 
For all categories of impact, transportation of the intensive green roof support layer causes 8 times greater impact than that related to the extensive green roof one. For intensive green roof, transportation of various materials is done by 3 types of transport: aerial, maritime and terrestrial, which not only involve very high value of climate change through emission of greenhouse gases but also consume fossil resources and release environmental pollutants. Indeed, these transportations emit into the atmosphere substances such as nitrogen oxide (NO) and sulfur dioxide $\left(\mathrm{SO}_{2}\right)$ with different emission rates. The impact of transportation is here dominated by maritime transport. To transport the protection layer, that related to intensive green roof is more impacting as aerial transport is used.

Emissions from the abovementioned transportations contribute to increasing the concentration of greenhouse gases in the atmosphere. They are responsible for the retention of heat as well as the diffraction of radiation contributing to climate change. On resource depletion, fuel consumption is more or less proportional to the traveled distance. With regard to human toxicity, the aircraft causes higher emissions compared to other types of transport means. Indeed, today's aircraft release high amounts of $\mathrm{CO}$ in the troposphere and stratosphere, which is hazardous to human health.

The travelled distances for the transportation of the respective substrate layers of both green roof types are identical but the amounts of transported materials are different, as transportation of the substrate layer for the intensive green roof is twice more impacting, that is, the impact is double for each impact category, than that related to the extensive one.

The transportation of the canopy layer is done by trucks. The impact is dependent on the load and the distance; the heavier is the load, the more pollutant is the transportation.

\subsection{Phase 3: Use Phase}

While the previous subsection results show that the use of intensive green roof is environmentally more impactful than the extensive green roof because of the difference of used materials and their amounts, the present subsection aims at scrutinizing the resource consumption according to the use patterns of both roof types in order to choose materials that allow saving resource.
As can be seen once more from Fig. 4, for every category of impact, intensive green roof is environmentally more impactful than the extensive green roof for all considered use phase lifetime span. Besides, impact magnitude on climate change of intensive green roof for 5 -year use phase is almost equivalent to that related to 10-year use phase of extensive green roof.

As being outlined previously, maintenance process mainly consists of adding fertilizer and watering periodically. The use of fertilizer from poultry is more advantageous over the compost use as fertilizer made of chicken droppings is produced on site without biological treatment which can lead to high energy consumption. Moreover, it also is convenient to water the green roof canopy with well water which can be pumped, for example, by photovoltaic devices.

\subsection{Suggestion of Some Solutions}

In this subsection, some improvement solutions for mitigating potential impacts are suggested. Some information allowing the choice of materials and means of transport to be used are presented as well.

To have a much lighter structure, a steel structure whose impact has already been studied by Olmez et al. [38] can be used instead of a concrete structure. However, it is better to choose wood for its ability to store $\mathrm{CO}_{2}$ [39]. The fact of using less plastic materials reduces the impact of the protection layer. It is beneficial to use manually crushed tile mixed with chicken droppings for the substrate layer. Whatever the vegetation types, the canopy layer is always of interest through its capacity of $\mathrm{CO}_{2}$ storage and dust collection.

Several means of transport were presented during the inventory. Air transport is dominant overall impact categories as it emits GHG and pollutants up to 8 times greater than maritime transport for the same quantity of carried loads. Besides, the amount of GHG emission related to intensive green roof protection layer is here 8 times greater than that of extensive green roof one. Although transportation has been included in previous studies (Kosareo and Ries [14]), its total environmental impact has not been quantified explicitly. In the present study, it has a very important part of impacts. As optimization solution, production in situ of materials is suggested. 


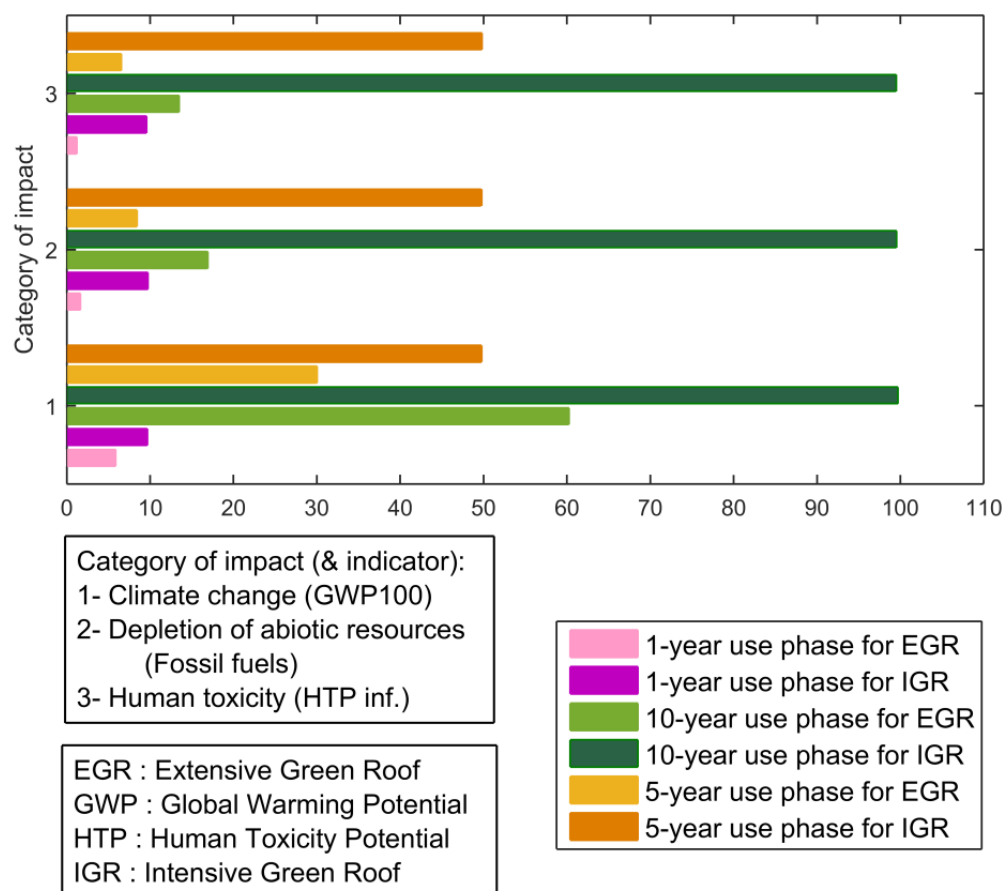

Fig. 4. Comparison of impacts during use phases of both green roof types

Adding the growth substrate and watering are always crucial when using green roofs. Therefore, their impacts are also to be considered. According to the above presented results, the impact of the use phase of intensive green roof is more important than that of the extensive green roof. Additionally, the poultry manure remains the best fertilizer as the quantity of added elements in intensive green roof is more than those related to the extensive green roof. One can assert that the impact of each material depends on its amount, its transport and especially of its characteristics. According to Fertilizers Europe and UNIFA (Union des industries de la fertilisation), finding an alternative to traditional fertilizer is important as composting waste products would be profitable. Hence, there is a sensitization for the use of the ammonitrate (an ammonium nitrate-based mineral fertilizer) that could reduce the carbon footprint by up to $25 \%$ [40]. And finally, the use of well water rather than tap water is advantageous for saving resource and energy.

\section{CONCLUSION}

The environmental performance of both lightweight and heavyweight green roof systems was analyzed to determine their potential environmental impacts. For that purpose, the respective impacts of different materials, transport and use of layers constituting the green roofs were calculated using free LCA tools. Based on the obtained results, it is possible to develop simple green roof systems using as less artificial materials as possible. Under the adopted assumptions in the present study, recycled products should be used instead of natural ones.

With respect to materials, it is better to choose lightweight materials from the support layer to the canopy layer. Improvements of the most impactful materials such as those used for the protection stratum and the substrate layer should be considered.

As far as transportation is concerned, it is reasonable to make maximum use of local products in order to avoid the high environmental impacts of international transport.

With regard to energy and resource consumption during the use phase of green roof: it can be asserted from the obtained comparison results that there is a huge difference between using compost and chicken manure as fertilizer in the substrate layer; it is more beneficial to utilize chicken manure. Moreover, the use of well water is also recommended for watering. 


\section{ACKNOWLEDGEMENTS}

The authors of this work are grateful to Bienvenue Raheliarilalao for her assistance on the use of LCA tools.

\section{COMPETING INTERESTS}

Authors have declared that no competing interests exist.

\section{REFERENCES}

1. Catalano C, Marcenò C, Laudicina VA, Guarino R. Thirty years unmanaged green roofs: Ecological research and design implications. Landscape Urban Plan. 2016;149:11-19.

DOI: 10.1016/j.landurbplan.2016.01.003

2. Gao T, Shen L, Shen M, Chen F, Liu L, Gao L. Analysis on differences of carbon dioxide emission from cement production and their major determinants. J Clean Prod. 2015;103:160-70.

DOI: 10.1016/j.jclepro.2014.11.026

3. Coma J, Pérez G, Solé C, Castell A, Cabeza LF. Thermal assessment of extensive green roofs as passive tool for energy savings in buildings. Renew Energ. 2016;85:1106-15.

DOI: 10.1016/j.renene.2015.07.074

4. Rakotondramiarana HT, Ranaivoarisoa TF, Morau D. Dynamic simulation of the green roofs impact on building energy performance, case study of Antananarivo, Madagascar. Buildings. 2015;5(2):497-20. DOI: 10.3390/buildings5020497

5. Anonymous. Etude pour la définition d'une démarche de développement des toitures végétalisées. Ernst \& Young. Nice Côte d'Azur, France; 2009.

(Accessed 15 May 2016)

Available:https://www.nice.fr/uploads/medi a/default/0001/02/Etude sur les toitures vegetalisees 1.pdf

6. Razzaghmanesh M, Beecham S, Salemi T. The role of green roofs in mitigating Urban Heat Island effects in the metropolitan area of Adelaide, South Australia. Urban For Urban Gree. 2016;15:89-102.

DOI: 10.1016/j.ufug.2015.11.013

7. Zhang Q, Miao L, Wang X, Liu D, Zhu L, Zhou B, Sun J, Liu J. The capacity of greening roof to reduce stormwater runoff and pollution. Landscape Urban Plan. 2015;144:142-50.

DOI: 10.1016/j.landurbplan.2015.08.017
8. Hashemi SSG, Mahmud HB, Ashraf MA. Performance of green roofs with respect to water quality and reduction of energy consumption in tropics: A review. Renew Sustain Energy Rev. 2015;52:669-79.

DOI: 10.1016/j.rser.2015.07.163

9. Bentley RW. Global oil \& gas depletion: An overview. Energ Policy. 2002;30(3): 189-05.

DOI: $10.1016 / S 0301-4215(01) 00144-6$

10. Yang $X$, Li $Y$. The impact of building density and building height heterogeneity on average urban albedo and street surface temperature. Build Environ. 2015;90:146-56.

DOI: 10.1016/j.buildenv.2015.03.037

11. Khasreen MM, Banfill PFG, Menzies GF. Life-cycle assessment and the environmental impact of buildings: A review. Sustainability. 2009;1:674-701. DOI: 10.3390/SU1030674

12. Cabeza LF, Rincón L, Vilariño V, Pérez G, Castell A. Life Cycle Assessment (LCA) and life cycle energy analysis (LCEA) of buildings and the building sector: A review. Renew Sustain Energy Rev. 2014;29:394416.

Available:http://dx.doi.org/10.1016/j.rser.20 13.08.037

13. Saiz S, Kennedy C, Bass B, Snail K. Comparative Life Cycle Assessment of standard and green roofs. Environ Sci Technol. 2006;40:4312-6.

DOI: $10.1021 / \mathrm{es} 0517522$

14. Kosareo L, Ries R. Comparative environmental Life Cycle Assessment of green roofs. Build Environ. 2007;42:260613.

DOI: 10.1016/j.buildenv.2006.06.019

15. Peri G, Traverso M, Finkbeiner M, Rizzo G. Embedding "substrate" in environmental assessment of green roofs life cycle: evidences from an application to the whole chain in a Mediterranean site. $\mathrm{J}$ Clean Prod. 2012;35:274-87.

DOI: 10.1016/j.jclepro.2012.05.038

16. Tselekis K. Literature review of the potential energy savings and retention water from green roofs in comparison with conventional one. Environ Clim Technol. 2012;9:40-45.

17. Hong TH, Kim JM, Koo CW. LCC and LCCO2 analysis of green roofs in elementary schools with energy saving measures. Energy Build. 2012;45:229-239. DOI: 10.1016/j.enbuild.2011.11.006 
18. Blackhurst M, Hendrickson $\mathrm{C}$, Matthews $\mathrm{H}$. Cost-effectiveness of green roofs. J Archit Eng. ASCE. 2010;136-143.

DOI:10.1061/(ASCE)AE.19435568.0000022

19. Bianchini F, Hewage K. How "green" are the green roofs? Lifecycle analysis of green roof materials. Build Environ. 2012;48:57-65.

DOI: 10.1016/j.buildenv.2011.08.019

20. Rivela B, Cuerda I, Olivieri F, Bedoya C, Neila J. Life Cycle Assessment for ecodesign of ecological roof made with Intemper TF ecological water-tank system [Análisis de Ciclo de Vida para el ecodiseño del sistema Intemper TF de cubierta ecológica aljibe]. Mater Construcc. 2013;63:131-45.

21. Molineux CJ, Fentiman $\mathrm{CH}$, Gange AC. Characterising alternative recycled waste materials for use as green roof growing media in the UK. Ecol Eng. 2009;35:150713.

DOI: 10.1016/j.ecoleng.2009.06.010

22. Chenani SB, Lehvävirta $S$, Häkkinen $T$. Life Cycle Assessment of layers of green roofs, J Clean Prod. 2015;90:153-62.

DOI: 10.1016/J.JCLEPRO.2014.11.070

23. Rincón L, Coma J, Pérez G, Castell A, Boer D, Cabeza LF, Environmental performance of recycled rubber as drainage layer in extensive green roofs: A comparative life cycle assessment. Build Environ. 2014;74:22-30.

DOI: 10.1016/j.buildenv.2014.01.001

24. Gargari C, Bibbiani C, Fantozzi F, Campiotti CA. Environmental impact of Green roofing: The contribute of a green roof to the sustainable use of natural resources in a life cycle approach. Agriculture and Agricultural Science Procedia. 2016;8:646-56.

DOI: 10.1016/j.aaspro.2016.02.087

25. Lamnatou Chr, Chemisana D, Photovoltaic-green roofs: A Life Cycle Assessment approach with emphasis on warm months of Mediterranean climate. $\mathrm{J}$ Clean Prod. 2014;72:57-75.

DOI: 10.1016/j.jclepro.2014.03.006

26. Lamnatou Chr, Chemisana D. Evaluation of photovoltaic-green and other roofing systems by means of ReCiPe and multiple life cycle-based environmental indicators. Build Environ. 2015;93:376-84.

DOI: 10.1016/j.buildenv.2015.06.031
27. Goedkoop M, Heijungs R, Huijbregts $M$, De Schryver A, Struijs J, Van Zelm R. ReCiPe 2008, A life cycle impact assessment method which comprises harmonised category indicators at the midpoint and 39 the endpoint level. $1^{\text {st }}$ ed. Report I: Characterisation, Netherlands: Ministerie van Volkshuisvesting, Ruimtelijke Ordening en Milieubeheer; 2013.

28. ILCD Handbook: Analysing of existing Environmental Impact Assessment methodologies for use in Life Cycle Assessment. $1^{\text {st }}$ ed. Italy: Joint Research Centre, TP 270 - 21027 Ispra (VA); 2010. (Accessed 24 May 2016)

Available:http://eplca.jrc.ec.europa.eu/uplo ads/ILCD-Handbook-LClA-Backgroundanalysis-online-12March2010.pdf

29. Goedkoop M, Oele M. SimaPro 5.1 User Manual: Introduction into LCA methodology and practice with SimaPro 5.1. The Netherlands: PRe'Consultants B.V.; 2002.

(Accessed 16 April 2016)

Available:http://www.sciencenetwork.com/l ca/UserManual.pdf

30. ISO 14040. Environmental management Life Cycle Assessment - principles and framework. Geneva: International Organization for Standardization; 2006.

31. ISO 14044. Environmental management Life Cycle Assessment -requirements and guidelines. Geneva: International Organization for Standardization; 2006.

32. Frischknecht $\mathrm{R}$, Jungbluth $\mathrm{N}$, Althaus $\mathrm{H}-\mathrm{J}$, Doka G, Dones R, Heck T, et al. The ecoinvent database: Overview and methodological framework (7pp). Int J Life Cycle Assess. 2005;10(1):3-9.

DOI: $10.1065 /$ lca2004.10.181.1

33. Ciroth A, ICT for environment in life cycle applications openLCA new open source software for life cycle assessment. Int $\mathrm{J}$ Life Cycle Assess. 2007;12(4):209-10. DOI: $10.1065 /$ lca2007.06.337

34. Acero AP, Rodríguez C, Ciroth A. LCIAmethods: Impact assessment methods in Life Cycle Assessment and their impact categories. Green Delta; 2015.

(Accessed 28 June 2016) Available:http://www.openlca.org/wpcontent/uploads/2015/11/LCIAMETHODS-v.1.5.4.pdf 
35. Peck S, Kuhn M. Lignes directrices de conception des toits verts. Ontario Association of Architects; 2002. French. (Accessed 15 June 2016)

Available:http://www.cebq.org/documents/ Lignesdirectricesdeconceptiondetoitsverts. pdf

36. Van Mechelen C, Dutoit T, Hermy M. Adapting green roof irrigation practices for a sustainable future: A review. Sustainable Cities and Society. 2015;19:74-90.

DOI: 10.1016/j.scs.2015.07.007

37. García-Pérez J, López-Abente G, Castelló A, González-Sánchez M, FernándezNavarro P. Cancer mortality in towns in the vicinity of installations for the production of cement, lime, plaster, and magnesium oxide. Chemosphere. 2015;128:103-10. DOI: 10.1016/j.chemosphere.2015.01.020
38. Olmez GM, Dilek FB, Karanfil T, Yetis U. The environmental impacts of iron and steel industry: A Life Cycle Assessment study. J Clean Prod. 2016;130:195-201. DOI: 10.1016/j.jclepro.2015.09.139

39. Guo Y, Zhao C, Chen X, Li C. $\mathrm{CO}_{2}$ capture and sorbent regeneration performances of some wood ash materials. Appl Energ. 2015;137:26-36.

DOI: 10.1016/j.apenergy.2014.09.086

40. Poidevin G. L'ammonitrate plus efficace et plus respectueux de l'environnement. Press conference given by the general delegate of UNIFA. France, 11 April; 2013. (Accessed 15 September 2016) Available:http://www.lafranceagricole.fr/act ualites/engrais-azote-l-ammonitrate-plusefficace-et-plus-respectueux-de-Ienvironnement-unifa-1,0,87030230.html

(c) 2017 Morau et al.; This is an Open Access article distributed under the terms of the Creative Commons Attribution License (http://creativecommons.org/licenses/by/4.0), which permits unrestricted use, distribution, and reproduction in any medium, provided the original work is properly cited. 